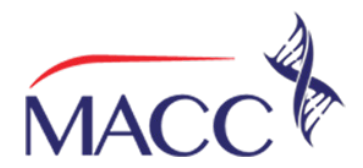

\title{
EMBOLI PARU PADA COVID-19
}

\section{Arie Zainul Fatoni ${ }^{{ }^{*}}$, Nasywa Florean Dzakiyyah ${ }^{1}$, Christian Ambrosius Soeiono ${ }^{1}$}

1. Departemen Anestesiologi dan Terapi Intensif, Fakultas Kedokteran Brawijaya, Malang, Jawa Timur, Indonesia

\begin{abstract}
ABSTRAK
COVID-19 adalah sebuah penyakit menular yang disebabkan oleh severe acute respiratory syndrome coronavirus-2 (SARS-CoV- 2) dan telah dinyatakan sebagai pandemi oleh WHO. Spektrum klinis penyakit ini begitu luas, mulai dari asimtomatik hingga acute respiratory distress syndrome (ARDS). Pada penyakit COVID-19, terdapat gangguan hiperkoagulabulitas dan hiperinflamasi/ cytokine storm, yang dapat menimbulkan komplikasi berupa emboli paru (EP). Gejala yang muncul biasanya berupa sesak, batuk, dan nyeri pleuritik; dengan tanda berupa takipneu, takikardi, dan sianosis pada keadaan yang parah. Penegakkan diagnosis EP dilakukan berdasarkan temuan klinis dan pemeriksaan penunjang. Sampai sekarang belum ada bukti yang cukup terkait penggunaan marker tertentu sebagai acuan diagnosis klinis dari EP. Berbagai ssistem skoring pun dibuat sebagai panduan untuk diagnosis dan juga sebagai upaya dalam melakukan stratifikasi risiko. Manajemen EP pada COVID-19 dibagi menjadi dua, yaitu terapi profilaksis dan terapeutik, baik secara farmakologis maupun non farmakologis. Prognosis EP COVID-19 lebih baik apabila dilakukan diagnosis dini dan tatalaksana dini berhasil dilakukan.
\end{abstract}

Kata Kunci: COVID-19, Emboli Paru, Heparin, Hiperinflamasi, Hiperkoagulabilitas 


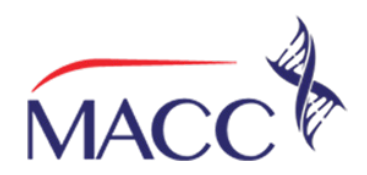

\title{
PULMONARY EMBOLISM IN COVID-19
}

\author{
Arie Zainul Fatoni ${ }^{1 *}$, Nasywa Florean Dzakiyyah ${ }^{1}$, Christian Ambrosius \\ Soeiono ${ }^{1}$
}

1. Department of Anesthesiology and Intensive Care, Faculty of Medicine, Universitas Brawijaya, Malang, Jawa Timur, Indonesia

*corresponding author

\begin{abstract}
COVID-19 is an infectious disease caused by severe acute respiratory syndrome coronavirus-2 (SARSCoV-2) and has been declared a pandemic by WHO. The clinical spectrum of this disease is very broad, ranging from asymptomatic to Acute Respiratory Distress Syndrome (ARDS). In COVID-19, there is a condition of hypercoagulation disorders and hyperinflammation/cytokine storms, which can cause complications in the form of pulmonary embolism. Symptoms usually include shortness of breath, coughing, and pleuritic pain; with signs of tachypnea, tachycardia, and cyanosis in severe circumstances. Diagnosis is made based on clinical findings and assisted by investigations, but there is still no evidence consistent with the use of certain markers as a clinical diagnosis of pulmonary embolism. Various scoring systems are established as a guide for diagnosis and also as an effort to stratify risks. Therapy that can be done is divided into two, namely prophylactic and therapeutic therapy, both pharmacologically and non-pharmacologically. Better prognosis of PE in COVID-19 patients depends on early diagnosis and successful early management.
\end{abstract}

Keywords: COVID-19, Pulmonary Embolism, Heparin, hyperinflammation, hypercoagulability 


\section{PENDAHULUAN}

World Health Organization (WHO) pada tahun 2020 menyatakan coronavirus disease 2019 (COVID-19) sebagai suatu pandemi. Spektrum klinis COVID-19 yang disebabkan novel severe acute respiratory syndrome coronavirus-2 (SARS-CoV-2) begitu luas, mulai dari asimtomatik hingga kondisi kritis yang memerlukan perawatan di ruang intensif. Angka mortalitas pada pasien COVID-19 dengan kondisi kritis sangat tinggi yaitu berkisar $20 \%$ - 90\%. Faktor risiko terkait meningkatnya keparahan penyakit dan risiko kematian COVID-19 adalah usia yang lebih tua, komorbid penyakit lain (hipertensi, diabetes mellitus, penyakit jantung dan penyakit paru paru), skor sequential organ failure assessment yang lebih tinggi (SOFA), dan D-dimer lebih tinggi. ${ }^{1}$ Manifestasi klinis pasien COVID-19 yang mengalami kondisi kritis sebagian besara adalah pasien dengan Acute Respiratory Distress Syndrome (ARDS), Acute Kidney Injury (AKI), kardiomiopati, komplikasi thrombosis (seperti emboli paru), sepsis dan syok sepsis. ${ }^{1,2}$

Pasien dengan COVID-19 yang kritis juga dapat menunjukkan gambaran hiperinflamasi sistemik atau cytokine storm/badai sitokin dan gangguan koagulasi. Gambaran gangguan koagulasi pada COVID-19 biasanya ditandai dengan level D-dimer dan produk degradasi fibrin yang meningkat. Beberapa laporan telah menunjukkan bahwa terdapat asosiasi antara hiperinflamasi sistemik dan juga profil koagulasi yang abnormal, serta dapat menyebabkan komplikasi yang mengancam jiwa yaitu emboli paru (EP). Sayangnya, sedikit yang diketahui tentang epidemiologi dan mekanisme patofisiologis yang mendasari EP terkait COVID-19 karena kurangnya studi prospektif dilakukan. Beberapa penelitian menyebutkan prevalensi EP pada pasien COVID-19 yang dirawat di rumah sakit sekitar 2,6 - 8,9 \%. Sedangkan pada pasien COVID-19 yang mengalami kondisi kritis angka kejadian EP meningkat sampai $30-60 \%$ walaupun pasien pasien sudah mendapat obat antikoagulan. ${ }^{2}$

Data otopsi postmortem pada 12 pasien di Jerman menyebutkan bahwa $58 \%$ pasien mengalami tromboemboli vena (TEV) padahal pasien pasien tersebut tidak ada tanda dan gejala TEV sebelum kematian. Pada otopsi lain juga menyebutkan bahwa penyebab kematian pasien pasien COVID-19 kemungkinan disebabkan oleh thrombosis pada arteri pulmonalis segmental dan subsegmental serta arteri pulmonalis yang kecil walaupun obat obatan antiokoagulan sudah diberikan. Hal tersebut semakin memperkuat dugaan bahwa EP dapat merupakan salah satu penyebab langsung dari kematian pada COVID-19. ${ }^{2,3}$ Oleh sebab itu pemahaman yang baik tentang diagnosis dini dan penanganan yang tepat terhadap EP pada COVID-19 sangatlah penting untuk menurunkan angka mortalitas pasien pasien COVID-19 dalam kondisi kritis yang dirawat di intensive care unit (ICU).

\section{Definisi}

Penyakit tromboemboli vena (TEV) adalah suatu spektrum penyakit yang mencakup trombosis vena dalam (TVD) dan emboli paru (EP). TVD terjadi akibat pembentukan gumpalan darah di dalam vena besar, biasanya di kaki. EP dapat disebabkan dariTVDyang telah putus dan berjalan ke sirkulasi arteri pulmonal. Untuk COVID-19 sendiri, selain EP yang ditimbulkan dapat berasal dari TVD, terdapat suatu keadaan yang disebut sebagai pulmonary microthrombosis (PMT). ${ }^{2,3}$

\section{Etiologi}

Severe acute respiratory syndrome coronavirus-2 (SARS-CoV- 2) termasuk dalam kelompok betacoronavirus yang mengandung RNA rantai tunggal (positive-sense) yang memiliki nukleoprotein di dalam kapsid yang terdiri dari protein matriks. Sebagai virus betacorona baru, SARS-CoV-2 memiliki kemiripan 79\% identitas urutan genom dengan SARS-CoV dan 50\% dengan Middle East Respiratory Syndrome Coronavirus (MERS-CoV2). ${ }^{4}$

SARS-CoV-2 'menjalankan aksinya' dengan berikatan dengan reseptor angiotensinconverting enzyme 2 (ACE2) melalui protuberansnya (spike), kemudian memasuki dan menginfeksi sel epitel alveolar, makrofag, dan selanjutnya virus tersebut akan melakukan transkripsi dan translasi gen.

Gejala utama infeksi SARS-CoV-2 ialah pada sistem pernapasan, tetapi dari beberapa penelitian terbaru diketahui juga bahwa infeksi dari SARS-CoV-2 dapat menimbulkan gangguan koagulasi yang dapat menimbulkan berbagai komplikasi, salah satunya adalah EP. ${ }^{4}$ 


\section{Epidemiologi}

Per 24 Mei 2020, 27 laporan kasus yang menggambarkan karakteristik klinis dari 30 pasien dengan EP terkait COVID-19 telah dipublikasikan. Usia rata-rata pasien ini adalah 59 tahun dengan 18 dari 30 pasien adalah lakilaki. Sepertiga dari kasus tidak memiliki kondisi komorbiditas sebelum masuk ICU dan sebagian besar $(80 \%)$ tidak ada sumber terjadinya EP yang terdeteksi.

Diagnosis EP rata-rata dibuat pada hari ke-11 sejak timbulnya gejala COVID-19. Fakta lain juga menunjukkan bahwa angka kejadian EP pada pasien COVID-19 tidak berhubungan dengan tingkat keparahan penyakit dan komorbid yang dimiliki pasien. ${ }^{2}$

Pasien dengan COVID-19 yang mengalami EP memiliki level d-dimer yang lebih tinggi, menunjukkan tingkat keparahan penyakit yang lebih tinggi dan respons inflamasi yang lebih nampak, dibandingkan mereka yang tidak mengalami EP. Hal ini juga sesuai dengan penelitian yang dilakukan oleh Alonso dkk ${ }^{2}$ dimana prevalensi EP banyak terjadi pada pasien dengan COVID-19 dengan kadar D-dimer lebih tinggi dari $1 \mu \mathrm{g} / \mathrm{mL}$. Selain itu, pasien dengan EP rata-rata berusia lebih tua dan memiliki marker inflamasi (jumlah trombosit, CRP) dan prokoagulan (D-dimer) yang lebih tinggi yang berkorelasi dengan kemungkinan penyakit tromboemboli yang lebih tinggi dibandingkan dengan pasien tanpa EP. ${ }^{5}$

Dalam studi observasional prospektif dari 150 pasien yang dirawat di empat ICU di dua rumah sakit Prancis, EP terjadi pada $16,7 \%$ pasien COVID-19 yang dirwat di ICU meskipun sudah diberikan obat - obatan tromboprofilaksis. ${ }^{6}$ Penelitian tersebut juga melaporkan bahwa kejadian tromboemboli lebih sering terjadi pada pasien COVID-19 dengan ARDS. Berdasarkan studi Lodigiani $\mathrm{dkk}^{7}$, insiden EP pada pasien rawat inap dengan COVID-19 dilaporkan sekitar 1,9-8,9\%. Namun, penelitian ini mempunyai kekurangan yaitu penelitian yang dilakukan bersifat retrospektif dari kelompok yang dilaporkan, dan periode follow up yang relatif singkat sehingga insiden EP yang ditemukan mungkin lebih rendah dari yang sebenarnya terjadi. $^{7}$

\section{Faktor Risiko}

Beberapa faktor risiko genetik, seperti faktor $V$ Leiden dan mutasi protrombin G20210A, telah diidentifikasi, tetapi hanya sebagian kecil penyakit tromboemboli vena yang disebabkan karena kondisi ini. ${ }^{3}$ Risiko TEV juga dikaitkan dengan faktor risiko terkait pasien individu, seperti usia, imobilisasi, obesitas, riwayat TEV baik personal maupun riwayat keluarga sebelumnya, kanker, sepsis, gagal napas atau jantung, kehamilan, stroke, trauma, atau pembedahan baru-baru ini. Faktor risiko khusus ICU juga dapat berkontribusi terhadap risiko ini, termasuk tetapi tidak terbatas pada sedasi, imobilisasi, pemberian vasopressor, dan penggunaan kateter vena sentral. ${ }^{2}$

\section{Patofisiologi}

Patogenesis infeksi SARS-CoV-2 pada manusia secara sederhana dapat dilihat melalui siklus hidup virus dengan inangnya yang terdiri dari 5 langkah berikut: perlekatan, penetrasi, biosintesis, pematangan dan pelepasan. Setelah virus mengikat reseptor inang (perlekatan), virus memasuki sel inang melalui endositosis atau fusi membran (penetrasi). Setelah isi virus dilepaskan di dalam sel inang, RNA virus memasuki nukleus untuk replikasi. mRNA virus digunakan untuk membuat protein virus (biosintesis). Kemudian, partikel virus baru dibuat (pematangan) dan dilepaskan. Replikasi cepat SARS-CoV-2 di paruparu dapat memicu respons imun yang kuat dan dapat bermanifestasi mulai dari gejala yang ringan hingga gejala yang berat. ${ }^{8}$

Mekanisme COVID-19 dalam meningkatkan risiko EP sendiri masih belum banyak diketahui. EP merupakan hasil dari trias klasik Virchow, yaitu gangguan endotel vaskular, stasis aliran darah, dan/atau peningkatan koagulabilitas. COVID-19 secara hipotetis dapat mempengaruhi semua 3 jalur tersebut. SARS-CoV-2 menggunakan angiotensin-converting enzyme receptor-2 (ACE-2) untuk masuk ke dalam sel pneumosit di paru-paru. ACE-2 ini juga diekspresikan pada sel endotel sehingga sel endotel juga dapat menjadi target virus ini. Selain itu, hipoksia, yang terjadi pada sebagian besar pasien yang sakit parah dengan COVID-19, dapat menyebabkan trombosis dengan meningkatkan viskositas darah dan dengan meningkatkan respons inflamasi sistemik. Terakhir, pasien dengan COVID-19 
yang parah dapat memicu keadaan sepsis yang dapat memicu pelepasan sitokin inflamasi seperti interleukin-6 (IL-6), interleukin-8 (IL8), tumor necrosis factor- $\alpha$ (TNF- $\alpha$ ) yang dapat memicu suatu cytokine storm. Hal tersebut juga dapat mendorong aktivasi gangguan hiperkoagulabilitas. Berikut akan dijabarkan secara lebih rinci terkait patofisiologi EP pada pasien pasien COVID-19 (Gambar 1$).{ }^{8}$

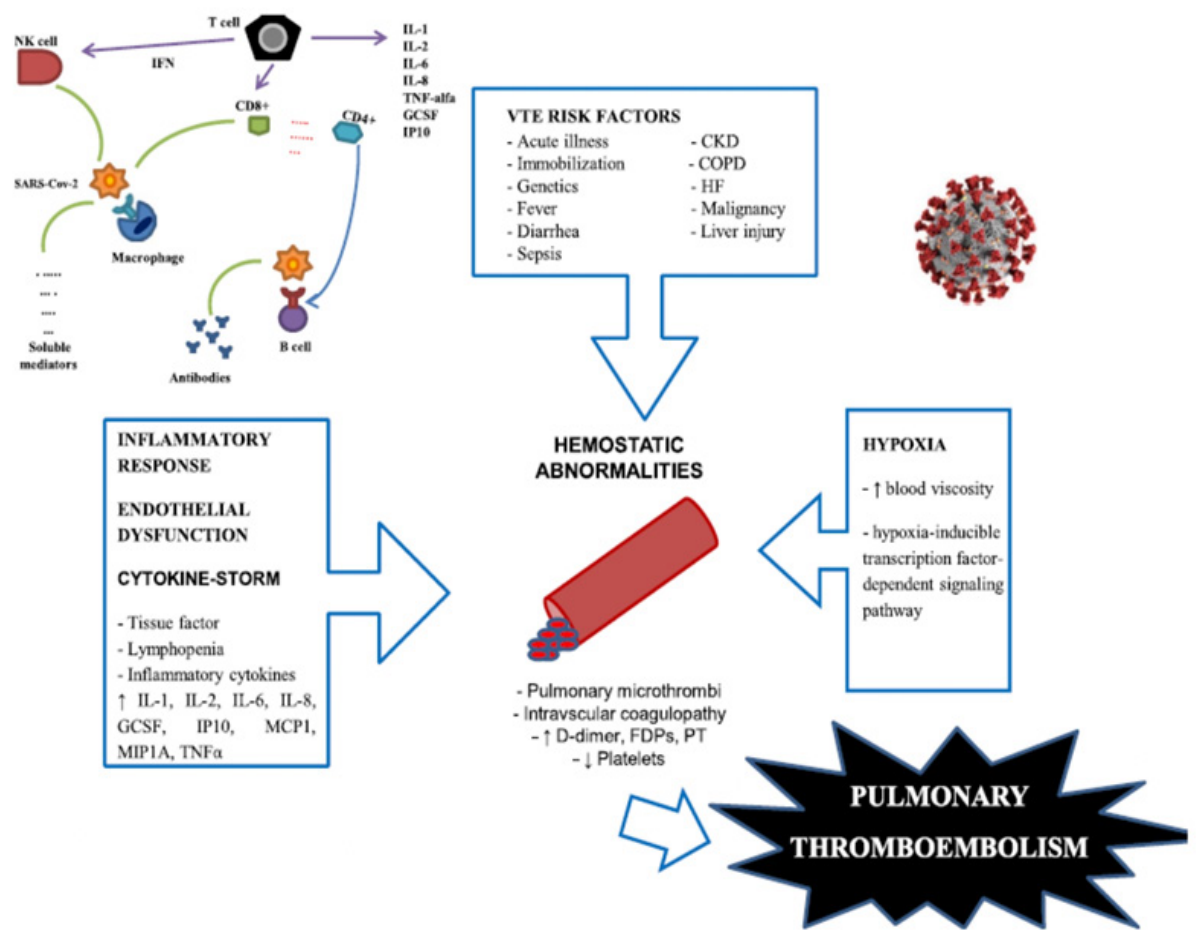

Gambar 1. Skema Patofisiologi yang Mendasari Terjadinya Emboli Paru pada Pasien COVID-19. CD: $C D$ receptor, CKD: chronic renal failure, COPD: chronic obstructive pulmonary disease, FDP: fibrin degradation products, GCSF: granulocyte-colony stimulating factor, HF: heart failure IFN: interferon, IL: interleukin, IP: interferon-gamma induced protein, MCP: monocyte chemotactic protein, MIP: macrophage inflammatory protein, NK: natural killer cells, PT: prothrombin time, SARS CoV-2: acute respiratory syndrome coronavirus 2, TNF alpha: tumor necrosis factor alpha ${ }^{8}$

\section{KEADAAN HIPERKOAGULASI DALAM COVID-19}

Terdapat beberapa mekanisme yang dapat berkontribusi pada keadaan hiperkoagulasi dan PMT pada COVID-19. Perlu diketahui, terdapat 2 aspek faktor pembentukan hiperkoagulabilitas dan penyakit trombotik: pertama, terdapat peningkatan koagulasi dan yang kedua adalah melemahnya antikoagulasi dan fibrinolisis. Reseptor ACE-2 merupakan komponen penting dari RAS (renin-angiotensin system) dan diekspresikan pada sel endotel vaskular. ACE2 secara bergantian mengubah angiotensin (Ang)-II menjadi Ang-(1-7) dan Ang I menjadi Ang-(1-9) (Gambar 2). Ang-(1-9) meningkatkan perkembangan trombosis, menurunkan konsentrasi plasma tissue plasminogen activator (t-PA), dan meningkatkan level plasminogen activator inhibitor-1 (PAI-1). Oleh karena itu, keseimbangan antara t-PA dan PAl-1 menjadi rusak dan produksi plasmin menjadi berkurang, sehingga meningkatkan risiko trombosis di pembuluh darah. ${ }^{8}$

Dari kaskade koagulasi, dapat dilihat bahwa peningkatan koagulasi dapat terjadi melalui jalur intrinsik atau ekstrinsik, yang menyebabkan meningkatnya faktor koagulasi dan pembentukan trombin. Banyak faktor yang menjadi activator dari sistem koagulasi, dan 


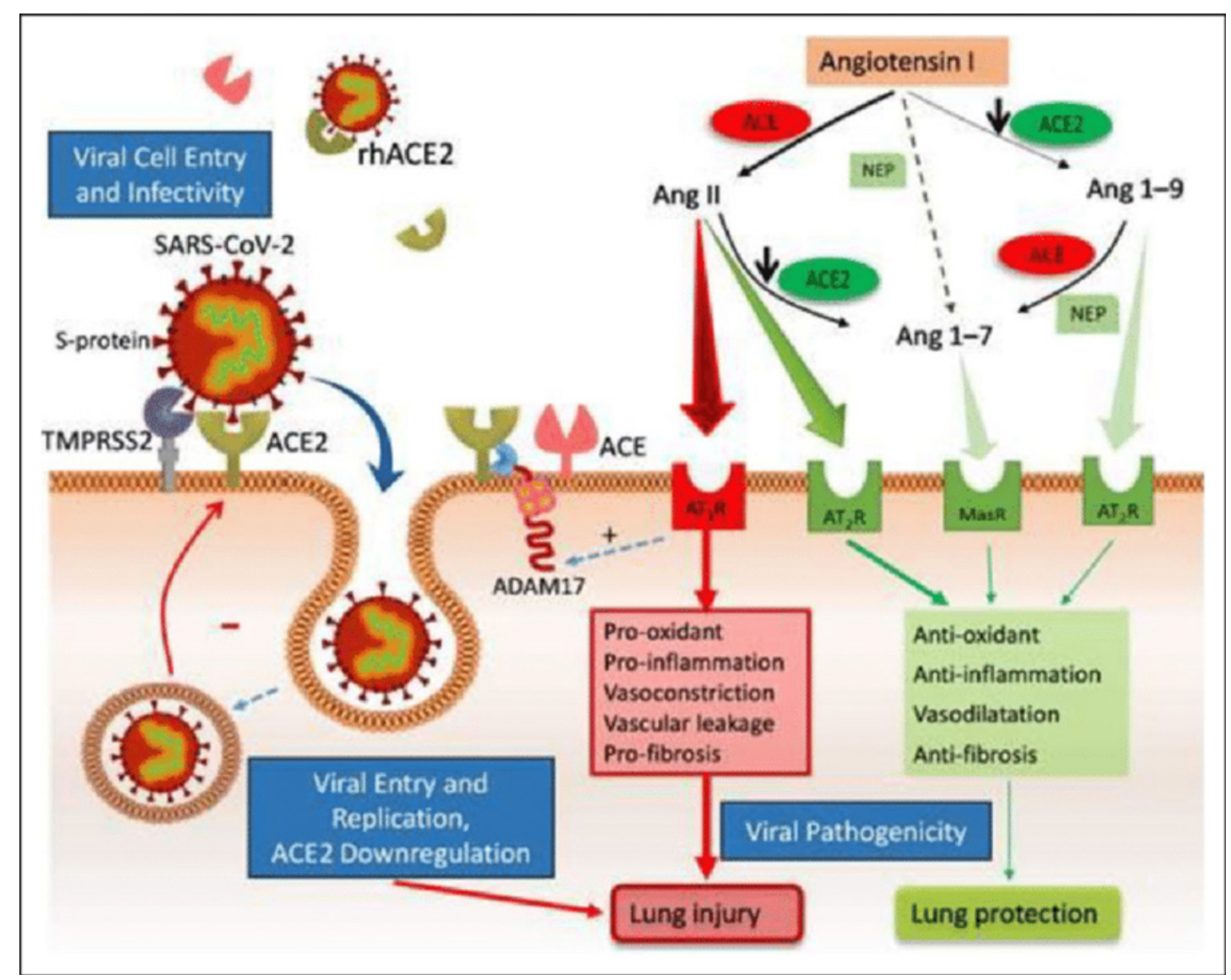

Gambar 2. Patogenesis SARS-CoV-2 yang Berikatan dengan Reseptor ACE-2 dan Mekanisme ACE-2 dalam Mempengaruhi Hiperkoagulabilitas Darah ${ }^{8}$

kerusakan pada endotel vaskular adalah pemicu utama terjadinya koagulasi. Inti dari sistem fibrinolitik adalah plasmin, yang digunakan untuk mendegradasi gumpalan benang-benang fibrin. Plasmin diaktivasi oleh plasminogen di bawah kendali t-PA dan kemudian dengan cepat bergabung dengan $a_{2}$-antiplasmin untuk membentuk kompleks plasmin-antiplasmin (PAP). Sel endotel vaskular mensekresikan t-PA, yang biasanya dalam bentuk kompleks tPA-PAI-1. Sel endotel vaskuler memiliki peran penting dalam mengatur sistem koagulasi, antikoagulasi, dan fibrinolisis dan terkait erat dengan keadaan hiperkoagulasi tubuh dan terjadinya penyakit trombotik. $^{8}$

Dari penjabaran di atas, diketahui bahwa SARSCoV-2 mengikat reseptor ACE-2 dan kemudian masuk ke dalam sel, menyebabkan kerusakan jaringan yang luas dan kerusakan sel endotel organ. Pada saat yang sama, aktivitas koagulasi yang menjembatani regulasi RAS meningkat tetapi aktivitas antikoagulasi dan fibrinolitik melemah, sehingga dapat menimbulkan trombosis yang ekstensif di pembuluh darah.

Apabila keadaan hiperkoagulabilitas ini terjadi secara ekstensif dan trombosis intravaskular terjadi secara difus, maka dapat menjadi penyebab terjadinya komplikasi seperti seperti EP. ${ }^{8}$ Selain itu, konsekuensi patologis langsung dan tidak langsung dari COVID-19, seperti hipoksia berat, penyakit penyerta yang sudah ada sebelumnya, dan disfungsi organ terkait dapat mempengaruhi kelainan hemostatik, salah satunya adalah disseminated intravascular coagulation (DIC). Hipoksia dapat mempengaruhi trombosis dengan meningkatkan viskositas darah dan melalui jalur pensinyalan yang bergantung pada faktor transkripsi yang diinduksi hipoksia. Terdapat juga peningkatan disfungsi endotel faktor von Willebrand (vWF), aktivasi Toll-like receptor (TLR), dan aktivasi jalur faktor jaringan dapat menginduksi efek proinflamasi dan 
prokoagulan melalui aktivasi komplemen dan pelepasan sitokin, mengakibatkan disregulasi kaskade koagulasi dengan pembentukan bekuan fibrin intra-alveolar atau sistemik. ${ }^{2}$

Pelepasan sitokin proinflamasi dengan jumlah tinggi pada plasma (IL-2, IL-6, IL-7, IL-8, granulocyte colony-stimulating factor, interferon gamma-induced protein 10 (IP10), monocyte chemotactic protein-1 ( MCP1), macrophage inflammatory protein $1 \mathrm{~A}$ (MIP1A) dan tumor necrosis factor (TNF- $\alpha$ )-yang disebut juga sebagai "badai sitokin/ cytokine storm", yang merupakan ciri umum dari sepsis, menyebabkan perkembangan limfohistiositosis hemofagositik dengan aktivasi koagulasi darah, meningkatnya risiko mikrotrombosis intravaskular yang mendorong terjadinya TEV. Aktivasi platelet saat pengenalan antigen dapat memfasilitasi klirens patogen melalui aktivasi sel darah putih dan pembentukan clot. Badai sitokin ini juga menyebabkan peningkatan risiko hiperpermeabilitas vaskular, kegagalan multiorgan, dan akhirnya kematian ketika konsentrasi sitokin yang tinggi tidak berkurang dari waktu ke waktu. ${ }^{9}$ Penelitian Middeldorp $\mathrm{dkk}^{10}$ menunjukkan bahwa jumlah sel darah putih, rasio neutrofil-limfosit yang tinggi dan level D-dimer yang tinggi merupakan faktor risiko independen yang terkait dengan TEV.

Penelitian Rouhezamin $\mathrm{dkk}^{11}$ menunjukkan bahwa pada orang dengan COVID-19, terdapat keadaan hiperkoagulasi yang ditunjukkan dengan tingkat d-dimer, fibrinogen, dan produk degradasi fibrinogen yang lebih tinggi, serta prothrombin time (PT), rasio normalisasi internasional (INR), dan thrombin time (TT) yang memanjang. Kelainan ini telah dikaitkan dengan prognosis yang buruk pada pasien yang terinfeksi SARSCoV-2. Penelitian Oudkerk dkk ${ }^{12}$ menunjukkan bahwa tingkat d-dimer yang sangat tinggi yang diamati pada pasien COVID-19 tidak hanya sebagai akibat sekunder dari adanya peradangan sistemik, tetapi juga mencerminkan penyakit trombotik yang sebenarnya, yang mungkin disebabkan oleh aktivasi seluler yang dipicu oleh virus. ${ }^{12}$ Penelitian Cui $\mathrm{dkk}^{13}$ menunjukkan bahwa nilai cut-off 3,0 $\mu \mathrm{g} / \mathrm{mL}$ untuk d-dimer memiliki sensitivitas, spesifisitas dan nilai prediksi negatif masing-masing 76,9\%, 94,9\% dan 92,5\% untuk memprediksi TEV. Infeksi virus SARS-CoV 2 dapat menjadi faktor predisposisi terjadinya TEV, mengaktifkan respon inflamasi sistemik yang dapat menyebabkan ketidakseimbangan antara prokoagulan dan antikoagulan. Jalur koagulasi dan sistem kekebalan memiliki keterkaitan antar satu sama lain. Pembentukan gumpalan dapat membatasi hilangnya darah dan komponen imunitas. Disamping itu, penggumpalan darah dapat memperlambat invasi mikroorganisme ke sistem sirkulasi. Hal ini disebabkan karena trombin dan trombosit juga memainkan peran penting dalam hubungan antara sistem kekebalan dan koagulasi. ${ }^{2}$

Pembentukan trombus pada mikrovaskulatur sebenarnya merupakan upaya fisiologis untuk membatasi viral load. Memang, invasi virus menyebabkan inflamasi pada paru-paru yang intens yang pada gilirannya dapat memicu aktivasi hemostasis lokal yang didorong oleh interaksi antara trombosit dan endotel. Diduga bahwa dasar dari pembentukan mikrotrombi pada pasien COVID-19 terkait dengan disfungsi sel endotel. ${ }^{14}$

Pola aktivasi koagulasi pada pasien ARDS COVID-19 di ICU tidak sama dengan pada pasien ARDS non-COVID-19 Pada ARDS nonCOVID-19, tingkat D-dimer kurang meningkat, $\mathrm{PT}$, activated partial thromboplastin time (aPTT), dan AT berada dalam kisaran normal, dan fibrinogen lebih tinggi. Pola ini juga berbeda dari yang diamati pada pasien dengan syok septik, yang sering berkembang menjadi DIC. Hal ini disebabkan karena mekanisme yang mendasari koagulopati yang diinduksi COVID-19 mungkin berbeda dari yang dilaporkan pada pasien lain dengan syok sepsis. ${ }^{2}$

Aktivasi jalur koagulasi selama respon imun terhadap infeksi menyebabkan produksi sitokin proinflamasi yang berlebihan yang dapat berujung pada kerusakan multiorgan. Meskipun fungsi utama trombinadalah untukmeningkatkan pembentukan gumpalan dengan mengaktifkan trombosit dan dengan mengubah fibrinogen menjadi fibrin, trombin juga memiliki beberapa efek seluler dan selanjutnya dapat memperkuat proses inflamasi melalui proteinase activated receptors (PARs), terutama PAR-1. PAR-1 adalah yang reseptor thrombin utama yang memediasi agregasi trombosit yang diinduksi trombin serta interaksi antara koagulasi, inflamasi, dan respons 
fibrotic. ${ }^{9}$

Pembentukan trombin dikontrol secara ketat oleh umpan balik negatif dan antikoagulan fisiologis, seperti antitrombin III, tissue factor pathway inhibitor, dan sistem protein C. Selama inflamasi, ketiga mekanisme kontrol ini dapat terganggu, dengan penurunan konsentrasi antikoagulan karena penurunan produksi dan peningkatan konsumsi. Keseimbangan prokoagulan dan antikoagulan yang rusak ini menjadi predisposisi perkembangan mikrotrombosis, DIC, dan kegagalan multiorgan yang dibuktikan pada kasus COVID-19 yang parah dengan peningkatan konsentrasi d-dimer menjadi fitur prognostik yang buruk. ${ }^{9}$ Akibat beberapa perubahan patologis tersebut, akan terjadi kelainan pertukaran gas, dimana yang paling umum dijumpai adalah adalah hipoksemia (penurunan PO2 arteri) dan peningkatan gradien tegangan oksigen alveolar-arterial, yang menunjukkan inefisiensi transfer oksigen melintasi paruparu. Ruang mati anatomis/ anatomic dead space bertambah karena gas yang dihirup tidak masuk ke unit pertukaran gas paru. Ruang mati fisiologis juga meningkat karena ventilasi ke unit pertukaran gas melebihi aliran darah vena melalui kapiler paru. ${ }^{3}$

Abnormalitas patofisiologi lainnya adalah sebagai berikut: ${ }^{3}$

1. Peningkatan resistensi vaskuler paru akibat obstruksi vaskuler atau sekresi platelet yaitu vasokonstriksi agen neurohumoral seperti serotonin. Pelepasan mediator vasoaktif dapat menghasilkan ventilation-perfusion mismatch di tempat yang jauh dari embolus

2. Gangguan pertukaran gas akibat peningkatan ruang mati alveolar akibat obstruksi vaskular, hipoksemia akibat hipoventilasi alveolar relatif terhadap perfusi di paru yang tidak mengalami obstruksi, right to left shunt, dan gangguan transfer karbon monoksida akibat hilangnya luas permukaan untuk pertukaran gas.

3. Peningkatan resistensi jalan nafas karena penyempitan saluran udara di distal bronkus

\section{MANIFESTASI KLINIS}

Tanda dan gejala EP kadang tidak khas bahkan tidak menunjukkan gejala/asimtomatik sehingga kadang EP timbul dengan kematian yang mendadak. Tanda dan gejala karakteristik yang mungkin dapat dijumpai adalah takikardia, dispnea, nyeri dada, hipoksemia, dan syok. Dalam penelitian Prospective Investigation of Pulmonary Embolism Diagnosis II (PIOPED II), pasien dengan EP memiliki berbagai tanda dan gejala. Tanda-tanda umum adalah takipnea (54\%) dan takikardia (24\%). Gejala yang paling umum adalah dispnea, biasanya timbul dalam hitungan detik, saat istirahat atau dengan aktivitas (73\%), nyeri pleuritik (44\%), nyeri betis atau paha (44\%), pembengkakan betis atau paha (41\%), dan batuk (34\%). ${ }^{15}$ Terdapat dua fenotipe utama pasien COVID-19 dengan penyakit paru trombotik yang dapat diidentifikasi: (1) pasien yang terkena TEV "biasa" dan (2) pasien yang menunjukkan PMT. Beberapa jurnal menunjukkan bahwa TVD atau sumber VTE lainnya tidak secara konsisten ditemukan pada pasien COVID-19 dengan EP. Oleh sebab itu PMT dianggap merupakan 'hasil' dari hiperkoagulabilitas lokal yang menyebabkan EP pada pasien dengan COVID-19 dan hal tersebut bukan diakibatkan oleh emboli yang lepas dari tungkai bawah. ${ }^{15}$

\section{Diagnosis}

Tanda dan gejala emboli paru dapat meniru atau tumpang tindih dengan gejala infeksi COVID-19 sehingga sulit untuk mengidentifikasi secara dini EP pada COVID-19. Oleh karena itu, setiap dokter yang mengevaluasi pasien dengan COVID-19 di tempat rawat jalan atau rawat inap harus memiliki ambang batas yang rendah untuk mempertimbangkan kejadian emboli paru yang terjadi secara bersamaan. Proses anamnesa yang baik dengan penggalian riwayat pasien seperti onset, keparahan, dan tingkat perkembangan gejala COVID-19, bersama dengan faktor risiko klasik tambahan untuk emboli paru, dapat memandu dokter dalam mengidentifikasi dini kejadian EP.16 Pada pemeriksaan fisik, adanya emboli paru pada infeksi COVID-19 (atau pada orang yang sedang diselidiki terinfeksi COVID-19) harus dipertimbangkan ketika pasien menunjukkan ketidakstabilan hemodinamik atau fungsi pertukaran gas buruk yang tidak sepenuhnya dapat dijelaskan atau tidak proporsional dengan stadium, durasi, dan laju perkembangan infeksi COVID-19. Misalnya pada pasien dengan infiltrat 
paru minimal dan ringan dengan gejala jangka pendek, tetapi disertai sinkop, syok, gagal napas akut, atau tanda overload ventrikel kanan akut. Untuk pasien dalam perawatan di rumah sakit dengan infeksi COVID-19 yang sudah pasti atau terduga, harus diterapkan kewaspadaan dan perhatian pada perkembangan tanda emboli paru yang bertumpang tindih dengan gangguan kardiorespirasi yang ada. Emboli paru khususnya harus dipertimbangkan jika pasien menunjukkan sesak napas onset akut, perburukan oksigenasi, hipotensi, atau takikardia, distensi vena jugular, denyut parasternal, peningkatan bunyi jantung kedua, murmur pada regurgitasi katup trikuspid, edema perifer dan nyeri dada, punggung, atau panggul terutama jika pencitraan atau temuan klinis tidak konsisten dengan memburuknya pneumonia COVID-19. Perubahan seperti ini harus memicu kebutuhan akan pemeriksaan diagnostik. ${ }^{2,17}$ Data dari Prancis menunjukkan bahwa EP yang terlihat pada pasien dengan COVID-19 rata-rata terjadi pada hari ke-6 sejak onset. ${ }^{17-19}$

Penggunaan biomarker seperti D-dimer untuk membantu mengidentifikasi pasien dengan COVID-19 yang berisiko mengembangkan tromboemboli vena telah dieksplorasi dalam beberapa seri kasus dan studi kohort. Dalam sebuah studi kohort pusat tunggal dengan 198 pasien, peningkatan D-dimer dikaitkan dengan peningkatan risiko sebesar 50\% untuk mengembangkan tromboemboli vena. ${ }^{10}$ Demikian pula dalam sebuah penelitian terhadap 400 pasien rawat inap dengan COVID-19, peningkatan D-dimer mencapai 1 hingga 2,5 $\mu \mathrm{g} /$ $\mathrm{mL}$ memiliki nilai OR untuk komplikasi trombotik sebesar 3,04 (95\% Cl, 1,26-7,31) dan D-dimer > $2,5 \mu \mathrm{g} / \mathrm{mL}$ memiliki nilai OR 6,79. (95\% Cl, 2,3919,30; $\mathrm{P}<0,001)$. Peningkatan D-dimer $>2,5 \mu \mathrm{g} /$ $\mathrm{mL}$ pada presentasi awal dapat memprediksi komplikasi perdarahan selama rawat inap. Data dari China juga menunjukkan bahwa pasien dengan risiko tertinggi untuk mengembangkan emboli paru adalah pasien yang sama dengan pasien yang memiliki risiko perdarahan tertinggi. ${ }^{19,20}$ Akan tetapi, pedoman American College of Chest Physicians menyatakan belum terdapat bukti yang cukup untuk merekomendasikan penggunaan peningkatan D-dimer atau data laboratorium lainnya untuk memandu diagnosis klinis EVD dan EP. ${ }^{20}$

Mengingat keterbatasan data untuk mendukung penggunaan biomarker untuk mendiagnosis EP pada pasien dengan COVID-19, pengujian diagnostik standar harus dipertimbangkan seperti dalam algoritma yang disusun oleh consortium pulmonary embolism response team (PERT) dan dapat dilihat di (Gambar 3). Diagnosa EP dapat ditegakkan dari pemeriksaan CT angiografi (CTA). CTA dengan multideteksi dapat melihat vaskularisasi pulmoner pada pasien yang disuspek suatu PE. Alat ini dapat memvisualisasikan arteri pulmonalis sampai ke level subsegmental. Pada studi The Prospective Investigation On Pulmonary Embolism Diagnosis (PIOPED) II menunjukkan CTA mempunyai sensitivitas $83 \%$ dan specifisitas $96 \%$ untuk mendiagnosa PE. Namun, karena kekhawatiran mengenai pajanan pada staf, tes diagnostik standar termasuk CTA mungkin tidak mudah untuk diperoleh. Sebagai alternatif, evaluasi foto thorkas, elektrokardiografi (EKG), ekokardiografi dan ultrasonografi ekstremitas bawah (area paha dan area fossa poplitea) dapat menjadi pemeriksaan tambahan yang penting dalam menegakkan diagnosis emboli paru. 17, 19, 21

Tanda EP pada gambaran foto thoraks sangat jarang terdeteksi tetapi jika ada akan muncul tanda Hampton hump (gambaran opasitas yang berbentuk wedge sebagai tanda infark) atau tanda Westermark (gambaran prominen pada proksimal arteri pulmonalis denga penurunan tanda pembuluh darah perifer). Pada EKG, gambaran yang biasanya muncul pada EP adalah sinus takikardia / atrial fibrilasi, regangan jantung kanan termasuk tanda S1Q3T3 (gelombang S di lead I, gelombang Q di lead III, dan inversi gelombang $T$ di lead III), inversi gelombang $T$ pada lead anterior dan elevasi segmen ST di lead inferior/anterior. EP akut dapat menyebabkan disfungsi dan peningkatan tekanan pada ventrikel kanan yang dapat dideteksi dengan ekokardiografi. Gambaran lain ekokardiografi yang mungkin pertanda suatu EP adalah adanya dilatasi atau disfungsi ventrikel kanan, trombus intrakardiak, kompresi interventricular septal atau gerakan septum yang paradoks, peningkatan regurgitasi tricuspid (jet velocity $>3.8 \mathrm{~m} / \mathrm{s}$ atau tricuspid valve peak systolic gradient $>60 \mathrm{mmHg}$ ), tanda 


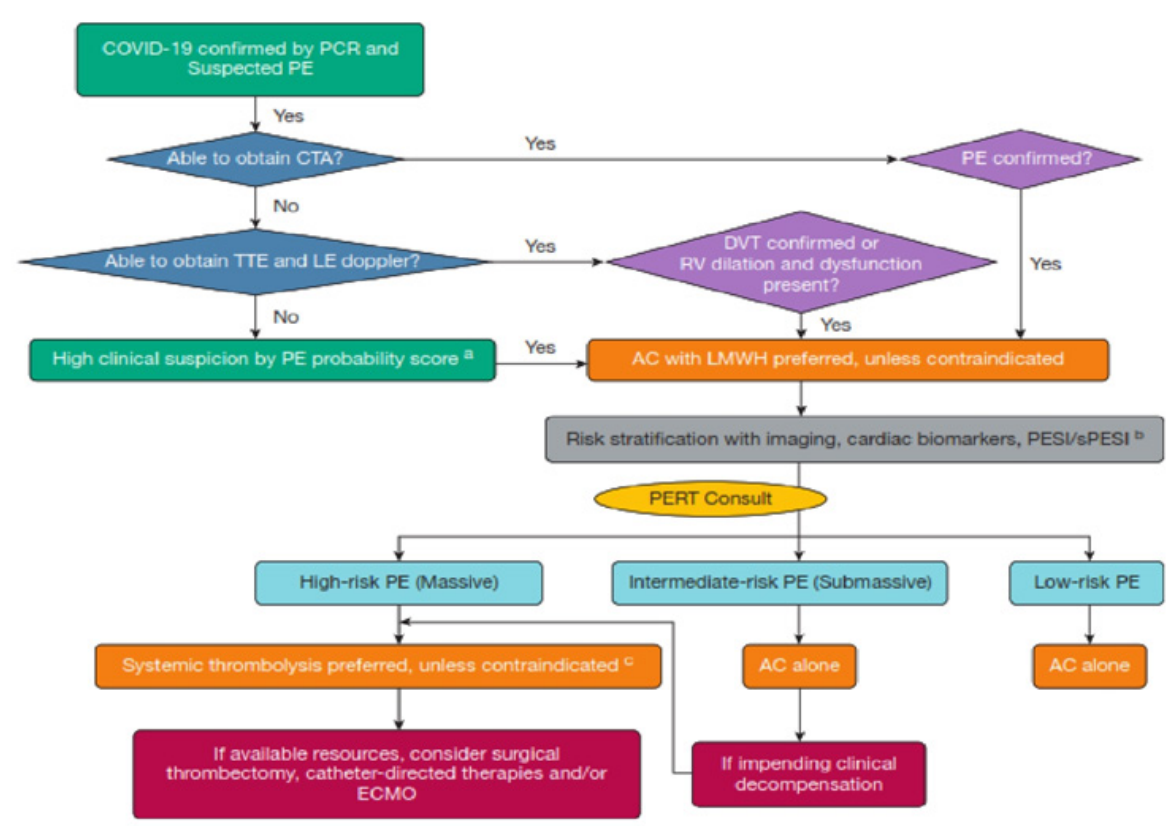

Gambar 3. Algoritma Pemeriksaan dan Tatalaksana Pasien COVID-19 dengan Kecurigaan Emboli Paru oleh Konsortium Tim Respon Emboli Paru (PERT). AC = anticoagulation; COVID-19= coronavirus disease 2019; $C T A=C T$ angiografi; $E C M O=$ extracorporeal membrane oxygenation; $L E$ = lower extremity; $L M W H=$ low-molecular-weight heparin; $P C R=$ polymerase chain reaction; $P E=$ pulmonary embolysm; $\mathrm{PERT}=$ pulmonary embolism response team; $\mathrm{PESI}=\mathrm{PE}$ severity index; $\mathrm{RV}=$ right ventricular; $\mathrm{SPESI}=$ simplified $\mathrm{PE}$ severity index; TTE $=$ transthoracic echocardiogram $^{16}$

McConnell's (hypokinesia pertengahan dinding jantung kanan yang bebas dengan pergerakan apek jantung kanan yang normal), tanda 60/60 (pulmonary ejection acceleration time $<60$ ms dan peak systolic tricuspid valve gradient $<60 \mathrm{mmHg}$ ) dan penurunan tricuspide annular plane systolic excursion (TAPSE). Pemeriksaan ultrasnografi (USG) untuk mengevaluasi adanya TVD juga sebaiknya dilakukan karena salah satu penyebab EP adalah lepasnya bekuan dari TVD. USG pada area paha (vena femoralis dan vena safena) dan fossa popltea (vena poplitea) kaki kanan-kiri dengan teknik kompresi dan dopler untuk melihat adanya hambatan aliran darah ataupun klot/kompresi vena yang inkomplet mempunyai sensitifitas $>90 \%$ dan spesifisitas 95\% untuk mendiagnosa adanya TVD. ${ }^{17,19,21}$

Secara umum alur deteksi dan diagnose EP pada COVID-19 dapat dilihat pada gambar 3 dimana secara umum skreeningnya dibagi menjadi tiga tahap yaitu 1) skrining dengan CTA, 2) skrining dengan USG/ekokardiografi dan yang ke-3) skrining dengan sistem skoring. Jika terdapat bukti mengenai dilatasi atau disfungsi ventrikel kanan, trombus intrakardiak, atau bekuan dalam transit yang akut atau tidak dapat dijelaskan, pasien harus dianggap menderita emboli akut dan pengobatan dengan antikoagulasi dosis penuh harus segera dimulai. ${ }^{22}$ Tidak ada gambaran ekokardiografi yang spesifik telah diidentifikasi untuk infeksi COVID-19. Bukti untuk adanya kelebihan tekanan sisi kanan seperti dilatasi ruang jantung sisi kanan, tanda McConnell, atau gerakan septum paradoks, meskipun tidak spesifik, tetap berperan sebagai sebuah temuan diagnostik. Demikian pula, jika teridentifikasi adanya atau sangat mungkin untuk terjadinya thrombosis vena dalam, pasien harus diobati dengan antikoagulasi dosis penuh. Kadang-kadang, pasien dengan COVID-19 mungkin tidak dapat dievaluasi dengan CTA, ultrasonografi, atau ekokardiogram karena kekhawatiran terpaparnya staf pada COVID-19 atau ketidakstabilan kardiorespirasi. Maka dalam kondisi ini, jika gambaran klinis mendukung emboli paru, pasien harus diobati dengan 
antikoagulasi dosis penuh, kecuali adanya kontraindikasi, sambil menunggu diagnosis pasti. Konsultasi dengan PERT (Pulmonary Embolism Response Team)dapatmembantumengklarifikasi diagnosis jika kemungkinan terdapat batasan dalam kesempatan pemeriksaan dan tumpang tindih antara gejala COVID-19 dan emboli paru. ${ }^{22}$ Gambaran klinis yang mendukung emboli paru dapat dipertimbangkan dari skor probabilitas yang mencakup kriteria Wells, skor Geneva, dan skor untuk eksklusi dengan Pulmonary Embolism Rule-out Criteria (terdiri dari 8 variabel : umur $<50$ tahun; laju nadi <100 kali per menit; $\mathrm{SpO} 2$ >94\%; tidak ada pembengkakan kaki unilateral; tidak ada hemoptisis; tidak mengalami trauma/ pembedahan; tidak ada riwayat TEV; tidak dalam terapi hormon). ${ }^{17,19,21}$

Setelah EP didiagnosis, stratifikasi risiko standar direkomendasikan menggunakan data gabungan dari tampilan klinis, tekanan darah sistolik, denyut jantung, laju pernapasan, kebutuhan oksigen, indeks keparahan emboli paru, pencitraan untuk disfungsi ventrikel kanan (CTA atau ekokardiogram), dan/atau biomarker (troponin, brain natriuretic peptide). Stratifikasi risiko terutama didasarkan pada kemampuan ventrikel kanan untuk mengatasi dampak beban yang disebabkan oleh trombus. PE akut dengan adanya hipotensi (didefinisikan sebagai tekanan darah sistolik [TDS] $<90 \mathrm{~mm}$ Hg selama> 15 menit, penurunan TDS sebesar $40 \mathrm{mmHg}$ atau lebih dari baseline, atau membutuhkan dukungan hemodinamik) dianggap EP berisiko tinggi (masif). Jika tidak ada hipotensi, stratifikasi lebih lanjut dengan menggunakan biomarker, pencitraan (CTA atau ekokardiografi), dan Pulmonary Embolism Severity Index (PESI) atau simplified Pulmonary Embolism Severity Index (sPESI) dapat dilakukan. ${ }^{22,17}$

Peningkatan troponin juga dapat terlihat pada infeksi COVID-19 sehingga mungkin mengganggu kegunaan klinisnya. Demikian pula, kardiomiopati terkait COVID-19 dapat menjadi penyebab lain dari disfungsi ventrikel kanan. Namun, adanya kardiomiopati tidak menyingkirkan diagnosis EP yang terjadi bersamaan dan mungkin memang menjadi faktor risiko independen untuk emboli paru akibat curah jantung yang buruk. Stratifikasi risiko harus memperhitungkan kontribusi relatif dari infeksi saluran pernafasan bagian bawah
COVID-19 atau emboli paru sebagai penyebab gagal pernafasan. Gangguan pernapasan dan hemodinamik dari pneumonia virus dan EP perlu diselidiki sepenuhnya untuk menentukan gangguan mana yang memiliki dampak terbesar dan untuk menentukan pengobatan yang optimal. Konsultasi dengan multidisiplin PERT,jika tersedia, direkomendasikan untuk membantu stratifikasi dan mempengaruhi pengambilan keputusan diagnostik dan terapeutik. ${ }^{22}$ Studi sebelum COVID-19 telah menunjukkan bahwa memiliki PERT dapat mengurangi waktu untuk menegakkan diagnosis emboli paru, waktu hingga pemberian antikoagulasi terapeutik, lamanya waktu perawatan di RS, dan kematian. ${ }^{19}$

\section{Terapi}

Sejauh ini, indikasi profilaksis pada infeksi COVID-19 sebagian besar didukung oleh data yang dikumpulkan dari pasien ICU yang sakit parah. Penelitian di Prancis memperluas pengetahuan yang ada mengenai pemberian profilaksis kepada pasien yang awalnya stabil. Prevalensi EP dalam populasi ini jauh lebih rendah, meskipun lebih terkait dengan intensitas infeksi seperti yang dinilai dari C-reactive protein (CRP), daripada kondisi-kondisi biasa yang diketahui mempengaruhi TEV seperti usia, obesitas, riwayat TEV, atau kanker. Di luar CRP, berdasarkan analisis multivariat, hanya ada beberapa faktor lain yang berkorelasi dengan keberadaan EP pada pasien COVID-19 yang dirawat di rumah sakit, yaitu jenis kelamin lakilaki, penundaan waktu dari kemunculan gejala awal hingga masuk rumah sakit, dan ada tidaknya pemberian antikoagulan sebelum diagnosis EP. Antikoagulasi profilaksis parenteral oral dikaitkan dengan insiden EP yang lebih rendah. Selain itu, prevalensi EP yang lebih tinggi ditemukan pada pasien dengan waktu yang lebih lama dari gejala awal hingga masuk rumah sakit dapat diartikan sebagai cerminan keterlambatan pengenalan profilaksis TEV parenteral. Secara keseluruhan, berdasarkan bukti yang ada, pendapat ahli yang muncul, dan hasil penelitian saat ini semuanya menyarankan inisiasi antikoagulasi profilaksis segera pada semua pasien rawat inap dengan COVID-19, terlepas dari ada atau tidak adanya faktor risiko biasa untuk TEV. ${ }^{21}$

International Society on Thrombosis 
and Haemostasis (ISTH) dan American Society of Hematology (ASH) baru-baru ini merekomendasikan dosis profilaksis low molecular weight heparin (LMWH) (enoksaparin $1 \times 40 \mathrm{mg}$ subkutan) atau unfractionated heparin (UFH) subkutan ( 3 x 5000 IU subkutan) harus dimulai pada semua pasien yang dicurigai atau dikonfirmasi COVID-19 yang dirawat di rumah sakit. Pada pasien dengan kemungkinan trombositopenia yang diinduksi heparin, peggunaan fondaparinuks dapat dipertimbangkan karena fondaprinuks juga efektif dalam mengurangi koagulopati yang diinduksi sepsis pada model hewan coba. Jika profilaksis farmakologis merupakan kontraindikasi, profilaksis tromboemboli vena mekanis (misalnya, kompresi pneumatik intermiten) harus dipertimbangkan pada pasien yang tidak bisa bergerak. Kombinasi profilaksis farmakologis dan mekanis umumnya tidak direkomendasikan. Penggunaan LMWH dosis menengah (misalnya, enoxaparin 4000 IU subkutan setiap 12 jam) dapat dipertimbangkan secara individual pada pasien dengan faktor risiko multipel untuk tromboemboli vena dan pada pasien COVID-19 dengan sakit kritis. Pada pasien obesitas, dosis berdasarkan berat badan yang lebih tinggi mungkin diperlukan,dengan dosis 7500 IU UFH tiga kali sehari atau enoxaparin 40 mg dua kali sehari. ${ }^{2}$

Dalam Pedoman Tatalaksana COVID-19 Indonesia setiap pasien yang dirawat dengan COVID-19, dilakukan pemeriksaan apakah memerlukan tromboprofilaksis dan tidak terdapat kontraindikasi pemberian antikoagulan. ${ }^{23}$ Pemberian antikoagulan profilaksis pada pasien COVID 19 derajat ringan harus didasarkan pada hasil pemeriksaan D- dimer. Pada setiap pasien COVID-19 rujukan pasien yang dirawat di RS dan dilakukan pemberian antikoagulan profilaksis. Untuk menentukan risiko kejadian TEV dikembangkan suatu model penilaian risiko yang merupakan suatu sistem skor risiko dan skor stratifikasi risiko kejadian komplikasi. Dengan mengetahui faktor-faktor risiko terjadinya TEV, dokter diharapkan dapat lebih bijak dan tepat dalam mengambil keputusan pasien yang akan diberikan profilaksis. Skor yang dipakai untuk menilai risiko TEV adalah skor PADUA yang dimodifikasi. Profilaksis diberikan jika nilai skor
PADUA modifikasi $>4.24$.

Kemudian dilakukan pemeriksaan kelainan sistem/organ dan komorbiditas sebagai penilaian resiko terjadinya perdarahan sebelum pemberian antikoagulan menggunakan Skoring Risiko Perdarahan IMPROVE. Jika tidak terdapat kontraindikasi (absolut/relatif) pada pasien tersebut (perdarahan aktif, riwayat alergi heparin atau heparin-induced thrombocytopenia, riwayat perdarahan sebelumnya, jumlah trombosit $<25.000 / \mathrm{mm} 3$, gangguan hati berat), pemberian antikoagulan profilaksis LMWH $1 \times$ 0,4 cc subkutan atau UFH 5.000 unit 2x sehari secara subkutan dapat dipertimbangkan pada pasien COVID-19 berat yang dirawat di rumah sakit. Hal lain yang harus dipertimbangkan sebelum memberikan antikoagulan adalah adanya penyakit komorbid seperti gangguan ginjal, atau pasien sudah dalam terapi antiplatelet seperti aspirin, clopidogrel atau obat antiplatelet lain (pada penderita penyakit jantung koroner, stroke atau penyakit lain). ${ }^{23,25}$ Berdasarkan panduan yang sama, peningkatan dosis profilaksis antikoagulan direkomendasikan pada pasien COVID-19 yang dirawat ICU atau post-ICU. Pemberian antikoagulan profilaksis pada pasien COVID-19 kondisi kritis mengikuti kriteria berikut ini:

Kriteria inklusi:

- Pasien terkonfirmasi COVID-19 atau PDP (Pasien Dalam Pemantauan) yang membutuhkan perawatan ICU dan/atau setelah dipindahkan dari perawatan ICU

- Trombosit lebih 25.000

Kriteria eksklusi:

- Jumlah tombosit kurang dari 25.000 atau memiliki manifestasi perdarahan

- Pasien bedah saraf (neurosurgery) atau memiliki perdarahan aktif

Monitoring anti-Xa pada pemberian LMWH dan activated partial thromboplastin time (aPTT) pada pemberian UFH secara rutin umumnya tidak diperlukan, namun dapat menjadi pertimbangan untuk menyesuaikan dosis bila ada risiko perdarahan. Target anti- Xa untuk profilaksis adalah 0,2-0,5 (puncak terapi dalam 4-6 jam setelah 3-4 injeksi). APTT sering kali memanjang pada pasien kritis sehingga tidak digunakan 
untuk menjadi penyesuaian dosis, kecuali bila dari awal terapi APTT tidak memanjang. ${ }^{23}$

Antikoagulasi terapeutik juga merupakan inti dalam pengelolaan pasien EP. Pemilihan agen yang tepat dan dosis yang tepat memerlukan pertimbangan komorbiditas yang mendasari, seperti disfungsi ginjal atau hati, trombositopenia, dan fungsi saluran pencernaan. Zhai et $\mathrm{al}^{29}$, merekomendasikan LMWH (mis., enoxaparin 100IU/kg dua kali sehari atau $150 \mathrm{IU} / \mathrm{kg}$ sekali sehari, atau nadroparin 86 $\mathrm{IU} / \mathrm{kg}$ dua kali sehari) sebagai pengobatan lini pertama. Pada gangguan ginjal berat, atau jika besar kemungkinan untuk dibutuhkan prosedur invasif, penggunaan UFH intravena diikuti dengan rute subkutan dilakukan dengan pemantauan rutin untuk penyesuaian dosis antikoagulasi. Berdasarkan Pedoman Tatalaksana COVID-19 Indonesia. ${ }^{23}$ Pada pasien COVID-19 yang mengalami emboli paru atau trombosis vena dalam, jika tidak terdapat kontraindikasi, harus diberikan antikoagulan dosis terapi berupa LMWH $1 \mathrm{mg} / \mathrm{kgBB}$ dua kali sehari subkutan atau UFH dengan dosis loading 80 unit/kgBB iv dilanjutkan drip kontinyu 18 unit/kgBB/jam dengan monitor APTT untuk menyesuaikan dosis dengan target 1,5-2,5x kontrol. Dosis UFH memerlukan titrasi dosis sesuai dengan nilai APTT, dapat dilihat pada (Tabel 1).

Direct oral anticoagulants (DOAC)/ obat oral antikoagulan hanya menjadi pilihan setelah fase akut lewat pada pasien stabil, dengan kelebihan berupa kurangnya kebutuhan untuk pemantauan sehingga memfasilitasi pemulangan tepat waktu dari rumah sakit dan manajemen rawat jalan. Meski demikian, potensi resiko DOAC terutama dalam kondisi disfungsi organ memungkinkan terjadinya penurunan keadaan klinis dan kurangnya agen pembalikan keadaan yang efektif di beberapa pusat kesehatan. EP yang berulang dalam keadaan telah diberikan antikoagulasi optimal dan tromboemboli vena yang signifikan secara klinis dalam kondisi kontraindikasi absolut pemberian antikoagulasi akan menjadi salah satu dari beberapa skenario di mana penempatan filter vena kava inferior dapat dipertimbangkan. Bahkan dalam kasus seperti ini, antikoagulasi harus dilanjutkan secepat mungkin. Pada pasien yang membutuhkan dosis terapi LMWH atau menerima terapi DOAC, fungsi ginjal, kadar

Tabel 1. Dosis Modifikasi Heparin berdasarkan Nilai APTT ${ }^{23}$

\begin{tabular}{ll}
\hline APTT (detik) & Dosis Modifikasi \\
\hline$<35$ detik (1,2x normal) & 80 unit/kg bolus, naik drip 4 unit/kg/jam dari sebelumnya \\
$35-45(1,2-1,5 x$ normal) & 40 unit/kg bolus, naik drip 2 unit/kg/jam dari sebelumnya \\
$46-70(1,5-2,3 x$ normal) & Tidak ada penyesuaian dosis \\
$71-90(2,3-3 x$ normal) & Turun drip 4 unit $/ \mathrm{kg} / \mathrm{jam}$ \\
$>90(>3 x$ normal) & Hentikan drip 1-2 jam. Mulai drip 3 unit/kg/jam \\
\hline
\end{tabular}

anti-faktor $\mathrm{Xa}$, dan kadar plasma DOAC harus dipantau. ${ }^{26}$

Pasien yang stabil secara hemodinamik dengan risiko menengah (risiko menengah-rendah atau risiko menengah-tinggi emboli paru menurut klasifikasi European Society of Cardiology (ESC); atau EP sub-masif menurut klasifikasi sebelumnya) harus dikelola dengan antikoagulasi dan pemantauan ketat. Jika kondisi tiba-tiba memburuk dengan tanda-tanda ketidakstabilan hemodinamik yang jelas (emboli paru masif atau berisiko tinggi dengan hipotensi atau henti jantung mendadak) dan bukti pada pemeriksaan bed-side ekokardiografi berupa onset baru adanya peningkatan beban ventrikel kanan atau hipertensi arteri pulmonalis, terapi trombolitik harus segera dimulai dengan memperhatikan kontraindikasi. Dosis dan agen yang tepat harus dipilih sesuai dengan protokol kelembagaan dan konsensus dari tim yang merawat. Terapi trombolitik membawa risiko perdarahan yang harus diperhitungkan dalam pengambilan keputusan klinis. Beberapa penelitian telah menyoroti risiko perdarahan pada pasien dengan COVID-19 memiliki angka yang bervariasi. $^{22}$ Beberapa agen trombolisis yang telah diterima 
sebagai regimen yang cocok diberikan pada emboli paru adalah: ${ }^{27}$

1. Recombinant tissue plasminogen activator (rtPA): $100 \mathrm{mg}$ dalam 2 jam atau $0.6 \mathrm{mg} / \mathrm{kg}$ dalam 15 menit. Dosis maksimal pemberian rtPA adalah $50 \mathrm{mg}$.

2. Streptokinase: 250.000 unit dalam 30 menit, diikuti dengan 100.000 unit/jam selama 1224 jam.

3. Urokinase: 4.400 unit dalam 10 menit, diikuti dengan 4.400 unit $/ \mathrm{kg} / \mathrm{jam}$ selama $12-24$ jam.

Dalam kasus syok refraktori atau henti jantung, extracorporeal membrane oxygenation (ECMO) bisa menjadi pilihan, dalam kombinasi dengan trombektomi bedah atau terapi yang menggunakan kateter sebagai upaya penyelamatan. ${ }^{28}$ Sebuah rekomendasi algoritma tatakalaksana emboli paru pada pasien COVID-19 diajukan oleh Adams dkk ${ }^{29}$ pada (Gambar 4) sebagai panduan dalam pemilihan terapi sesuai kondisi pada pasien COVID dengan emboli paru. Mengingat tidak adanya manfaat yang jelas untuk terapi invasif dan besarnya potensi penularan virus, pendekatan konservatif yang condong ke terapi medis harus dipertimbangkan pada pasien dengan COVID-19. Secara umum, cara prosedural untuk mengobati EP harus diterapkan hanya pada kasus yang parah di mana terapi medis tidak mungkin berhasil atau terdapat kontraindikasi. ${ }^{22}$

Efek prokoagulan dari infeksi COVID-19 dapat diperpanjang beberapa minggu setelah pemulangan dari rumah sakit pada pasien yang tampaknya stabil dan tanpa gejala. Oleh karena itu, dapat dicurigai adanya emboli paru pada pasien COVID-19 yang masuk kembali ke rumah sakit setelah sempat dipulangkan dari rawat inap awal. Keputusan tentang perpanjangan terapi profilaksis dengan LMWH setelah pasien keluar dari rumah sakit dari penyakit medis akut harus dibuat dengan mempertimbangkan keseimbangan antara penurunan risiko TEV dengan risiko peningkatan kejadian perdarahan. Karena belum adanya bukti yang kuat, profilaksis farmakologis dalam konteks ini harus disediakan untuk pasien dengan risiko tertinggi saja, termasuk pasien dengan mobilitas terbatas dan riwayat tromboemboli vena sebelumnya atau keganasan aktif. ${ }^{26}$ Seperti yang direkomendasikan oleh Italian Society on Thrombosis and Haemostasis (SISET),

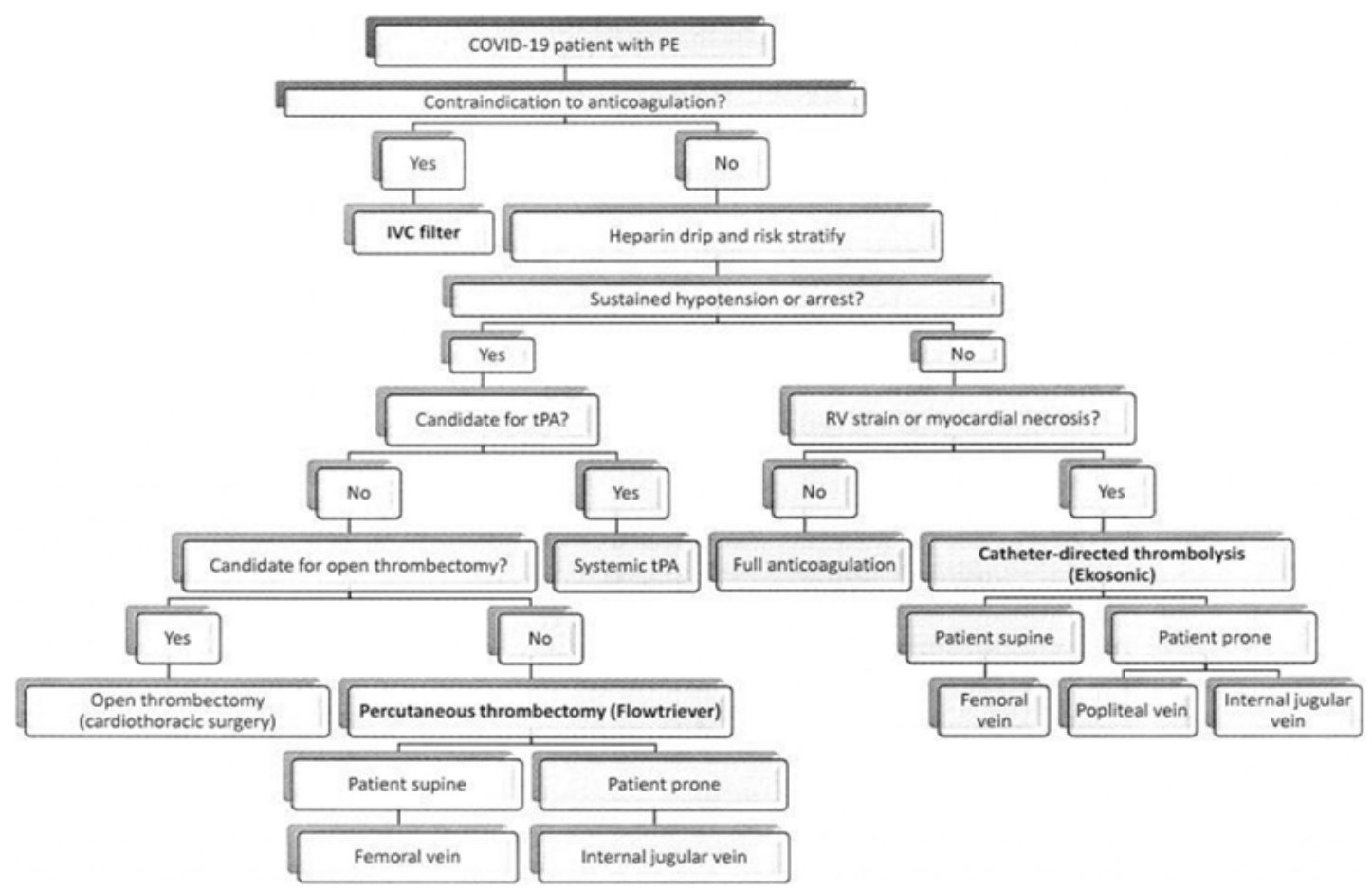

Gambar 4. Algoritma Tatalaksana Emboli Paru pada Pasien COVID-1929 
antikoagulasi profilaksis harus dipertahankan di rumah selama 7-14 hari setelah keluar dari rumah sakit atau dalam fase pra-rumah sakit selama dilakukan isolasi di rumah, dalam kasus pasien dengan faktor risiko tromboemboli vena yang sudah ada atau menetap (yaitu, mobilitas yang berkurang, indeks massa tubuh (BMI)> 30 $\mathrm{kg} / \mathrm{m}^{2}$, TEV sebelumnya, kanker aktif, dll). ${ }^{30}$

\section{Prognosis}

Dengan meningkatnya laporan emboli paru setelah infeksi COVID-19, temuan menunjukkan bahwa emboli paru berkembang pada 2 dari 10 pasien, di antara total 1.835 pasien COVID-19. Imobilisasi, peradangan, koagulasi yang diaktifkan, dan penekanan fibrinolisis telah diusulkan untuk menjelaskan terjadinya emboli paru pada pasien COVID-19; Namun, kejadian emboli paru pada pasien COVID-19 lebih tinggi jika dibandingkan pada pasien dengan pandemi influenza dan influenza musiman (3\%). Selain itu, laporan yang ada juga menunjukkan bahwa pasien COVID-19 dengan emboli paru memiliki tingkat kematian hingga $45 \%$ lebih tinggi dibandingkan dengan kasus umum (tingkat kematian di rumah sakit 4\%). Oleh karena itu, penyedia layanan kesehatan lini pertama harus waspada tentang terjadinya komplikasi emboli paru yang parah dan berpotensi fatal pada pasien COVID-19. ${ }^{31}$ Emboli paru adalah diagnosis menantang yang dapat terabaikan karena presentasi klinisnya yang tidak spesifik. Namun, diagnosis dini menjadi sangat penting, karena pengobatan yang tepat waktu sangat efektif dan secara signifikan mempengaruhi hasil klinis. ${ }^{1}$

\section{KESIMPULAN}

Penyakit Coronavirus 2019 (COVID-19) masih menjadi pandemi global dengan angka pasien yang meningkat, dengan morbiditas dan mortalitas yang signifikan. Komplikasi parah dari COVID-19 yang terkait dengan perubahan koagulasi, terutama ditandai dengan peningkatan D-dimer dan tingkat fibrinogen dengan risiko trombosis yang lebih tinggi, khususnya emboli paru. Koeksistensi penyakit coronavirus 2019 (COVID-19) dan emboli paru (PE) sebagai dua penyakit yang mengancam jiwa pada pasien yang sama menghadirkan tantangan unik dalam tatalaksananya. Beberapa panduan telah menjelaskan cara terbaik untuk mendiagnosis dan mengelola pasien dengan $P E$, namun, aspek unik dari infeksi COVID-19 mengacaukan diagnosis dan pengobatan PE sehingga diperlukan modifikasi algoritme yang mapan dalam alur diagnosis dan tatalaksananya. Pertimbangan penting termasuk penyesuaian modalitas diagnostik, penggabungan kontribusi prothrombotik COVID-19, pengelolaan dua penyakit kardiorespirasi kritis pada pasien yang sama, dan keutamaan perlindungan bagi pasien dan petugas kesehatan sambil mempertahankan pemberian perawatan yang optimal. Salah satu pendekatan diagnosis dan tatalaksana yang bisa diterapkan didasarkan pada pendekatan multidisiplin dengan PERT, yang secara signifikan dapat membantu dalam perawatan pasien yang rentan dan rumit ini. Melalui diskusi klinis multidisiplin, evaluasi PERT menilai status hemodinamik, memberikan evaluasi kardiopulmoner, menimbang dampak kondisi komorbiditas, dan menentukan antikoagulasi atau manajemen intervensi terbaik yang akan dilakukan. Kewaspadaan dan tindakan khusus juga diperlukan dalam menangani pasien tersebut untuk mengoptimalkan hasil sambil melindungi staf medis yang ikut berperan.

\section{DAFTAR PUSTAKA}

1. Zhou F, Yu T, Du R, et al. Clinical course and risk factors for mortality of adult inpatients with COVID-19 in Wuhan, China: a retrospective cohort study. Lancet. 2020;395(10229):105462.

2. Sakr Y, Giovini M, Leone M, et al. Pulmonary embolism in patients with coronavirus disease-2019 (COVID-19) pneumonia: a narrative review. Ann Intensive Care. 2020;10(1).

3. Jameson JL, Fauci AS, Kasper DL, Hauser SL, Longo L, Loscalzo J. Harrison's principles of internal medicine 18E Vol 2 EB. In: Harrison's Principles of Internal Medicine. McGraw Hill Education; 2020:9-14.

4. Yuki K, Fujiogi M, Koutsogiannaki S. Since January 2020 Elsevier has created a COVID-19 resource centre with free information in English and Mandarin on the 
novel coronavirus COVID- 19 . The COVID-19 resource centre is hosted on Elsevier Connect, the company' s public news and information . 2020;(January).

5. Alonso-Fernández A, Toledo-Pons N, Cosío $B G$, et al. Prevalence of pulmonary embolism in patients with COVID-19 pneumonia and high D-dimer values: A prospective study. PLoS One. 2020;15(8 August 2020):1-15.

6. Helms J, Tacquard C, Severac F, et al. High risk of thrombosis in patients with severe SARS-CoV-2 infection: a multicenter prospective cohort study. Intensive Care Med. 2020;46(6):1089-98.

7. Lodigiani C, lapichino G, Carenzo L, et al. Venous and arterial thromboembolic complications in COVID-19 patients admitted to an academic hospital in Milan, Italy. Thromb Res. 2020;191(April):9-14.

8. Haimei MA. Pathogenesis and Treatment Strategies of COVID-19Related Hypercoagulant and Thrombotic Complications. Clin Appl Thromb. 2020;26(168):1-5.

9. Amit Kumar Mandal, Paulami Dam , Octavio L. Franco, Hanen Sellami, Sukhendu Mandal , Gulten Can Sezgin , Kinkar Biswas, Partha Sarathi Nandi IO. Since January 2020 Elsevier has created a COVID-19 resource centre with free information in English and Mandarin on the novel coronavirus COVID-. Ann Oncol. 2020;(January):19-21.

10. Middeldorp S, Coppens $M$, van Haaps TF, et al. Incidence of venous thromboembolism in hospitalized patients with COVID-19. J Thromb Haemost. 2020;18(8):1995-2002.

11. Rouhezamin MR HS. Diagnosing Pulmonary Thromboembolism in COVID-19: A Stepwise Clinical and Imaging Approach. Acad Radiol. 2020;27(6)::896-7.

12. Oudkerk $M$, Buller HR, Kuijpers $D$, et al. Diagnosis, prevention, and treatment of thromboembolic complications in COVID-19: Report of the national institute for public health of the Netherlands. Radiology. 2020;297(1):E216-E222.

13. Cui S, Chen S, Li X, Liu S, Wang F. Prevalence of venous thromboembolism in patients with severe novel coronavirus pneumonia. J Thromb Haemost. 2020;18(6):1421-4. doi:10.1111/jth.14830

14. Mosleh W, Chen K, Pfau SE, Vashist A. Endotheliitis and Endothelial Dysfunction in Patients with COVID-19: Its Role in Thrombosis and Adverse Outcomes. J Clin Med. 2020;9(6):1862.

15. Thachil J SA. SARS-2 Coronavirus-associated hemostatic lung abnormality in COVID-19: is it pulmonary thrombosis or pulmonary embolism? Semin Thromb Hemost. 2020.

16. Rosovsky RP, Grodzin C, Channick R, et al. Diagnosis and Treatment of Pulmonary Embolism During the Coronavirus Disease 2019 Pandemic: A Position Paper From the National PERT Consortium. Chest. 2020.

17. Konstantinides S V., Meyer G, Galié N, et al. 2019 ESC Guidelines for the diagnosis and management of acute pulmonary embolism developed in collaboration with the European Respiratory Society (ERS). Eur Respir J. 2019;54(3).

18. Poissy J, Goutay J, Caplan M, et al. Pulmonary Embolism in Patients with COVID-19: Awareness of an Increased Prevalence. Circulation. 2020;142(2):184-6.

19. Chaudhury P, Gadre S, Schneider E, et al. Impact of Multidisciplinary Pulmonary Embolism Response Team Availability on Management and Outcomes. Am J Cardiol. 2019;124(9):1465-9.

20. Moores LK, Tritschler T, Brosnahan S, et al. Prevention, Diagnosis, and Treatment of VTE in Patients With Coronavirus Disease 2019: CHEST Guideline and Expert Panel Report. Chest. 2020;158(3):1143-63.

21. Torbicki A. COVID-19 and pulmonary embolism: An unwanted alliance. Eur Heart J. 2020;41(32):3069-71.

22. Rivera-Lebron B, McDaniel M, Ahrar K, et al. Diagnosis, Treatment and Follow Up of Acute Pulmonary Embolism: Consensus Practice from the PERT Consortium. Clin Appl Thromb. 2019;25.

23. Burhan $E$, Susanto $A D$, Nasution $S A$, et al. Pedoman Tatalaksana COVID-19. Edisi 2. Jakarta: PDPI, PERKI, PAPDI, PERDATIN, dan IDAl; 2020.

24. Kurnianda J, Darmawan B, Djamaludin N, Setiawan B, C. S. Profilaksis Tromboemboli Vena Pada Medik. In: Panduan Nasional 
Tromboemboli Vena. ; 2018.

25. Dobromirski M, Cohen AT. How I manage venous thromboembolism risk in hospitalized medical patients. Blood. 2012;120(8):15629.

26. Bikdeli B, Madhavan M V., Jimenez D, et al. COVID-19 and Thrombotic or Thromboembolic Disease: Implications for Prevention, Antithrombotic Therapy, and Follow-Up: JACC State-of-the-Art Review. J Am Coll Cardiol. 2020;75(23):2950-73.

27. Octaviani F, Kurniawan A. Emboli Paru. Medicinus. 2018;4(9):313-22.

28. Zhai Z, Li C, Chen Y, et al. Prevention and Treatment of Venous Thromboembolism Associated with Coronavirus Disease
2019 Infection: A Consensus Statement before Guidelines. Thromb Haemost. 2020;120(6):937-48.

29. Adams E, Broce M, A. M. Proposed Algorithm for Treatment of Pulmonary Embolism in COVID-19 Patients. Ann Vasc Surg. 2020;S0890-509.(20):30768-8.

30. Marietta M, Ageno W, Artoni A, et al. COVID-19 and haemostasis: A position paper from Italian Society on Thrombosis and Haemostasis (SISET). Blood Transfus. 2020;18(3):167-9.

31. Liao SC, Shao SC, Chen YT, Chen YC, Hung MJ. Incidence and mortality of pulmonary embolism in COVID-19: A systematic review and meta-analysis. Crit Care. 2020;24(1):1-5. 